\title{
Seasonal and interannual variations in diatom assemblages in Murray River connected wetlands in north-west Victoria, Australia
}

\author{
Peter A. Gell ${ }^{\mathrm{A}, \mathrm{D}}$, Ian R. Sluiter ${ }^{\mathrm{B}}$ and Jennie Fluin ${ }^{\mathrm{C}}$ \\ ${ }^{A}$ Department of Geographical and Environmental Studies, University of Adelaide, SA 5005, Australia. \\ ${ }^{B}$ Ogyris Ecological Research Pty Ltd, Dow Ave., Birdwoodton, Vic. 3505, Australia. \\ ${ }^{\mathrm{C}}$ Department of Geography and Environmental Science, Monash University, Clayton, Vic. 3168, Australia. \\ ${ }^{D}$ Corresponding author; email: peter.gell@adelaide.edu.au
}

\begin{abstract}
Epipelic diatom assemblages collected from three wetlands connected to the Murray River displayed considerable variation in response to flooding and drying phases. Murray River water input usually generated diatom assemblages dominated by Aulacoseira species. After isolation, the diatom flora of two wetlands shifted to assemblages of small Fragilariaceae forms. Elevated nutrient levels corresponded with the appearance of eutraphentic taxa such as Cyclotella meneghiniana, Eolimna subminuscula, Luticola mutica and Nitzschia palea. Further evapoconcentration induced shifts to taxa tolerant of elevated salinity levels including Amphora coffeaeformis, Navicula incertata, Staurophora salina and Tryblionella hungarica. Ordination analyses reveal a strong chemical control on the diatom taxa present in the wetlands, in accordance with known ecological preferences for salinity and nutrients. The influence of nitrogen and phosphorus concentrations in controlling diatom assemblages was subordinate to salinity once conductivity values exceeded $1400 \mu \mathrm{S} \mathrm{cm}^{-1}$. The results of such biomonitoring provide a means of interpreting wetland history from fossil assemblages contained in sediment sequences.
\end{abstract}

\section{Introduction}

An understanding of the temporal variation within an aquatic ecosystem requires the monitoring of communities over a range of time scales. Diatoms provide a simple and time-efficient means of biomonitoring wetlands because they are abundant and are easy to collect (Dixit et al. 1992; Reid et al. 1995). This facilitates regular sampling that can provide insights of seasonal variation and, where support is maintained over longer periods, of interannual variability. This is particularly important because, in Australia, rarely is any year typical of the average climate or hydrological conditions. In fact, in the boom-and-bust ecologies (sensu Walker et al. 1997) of Australian semiarid systems, longer-term, interannual monitoring is essential if the full range of impacts and responses over time are to be gauged. To gain an even longer-term perspective, a palaeoecological approach may be used (see Thoms et al. 1999; Bulpin 2000). This approach provides evidence on changes to systems at time scales spanning from decades to centuries and beyond. Palaeoecological studies are themselves informed by insights from shorterterm biomonitoring studies and so, as Davis (1987) suggests, the ideal approach to understanding ecosystem variation may be to undertake a complementary approach of long-term monitoring in concert with paleoecological studies.

The floodplain of the lower Murray-Darling Basin is subject to acute salinization owing to long-term hydrological imbalance brought about by imprudent irrigation practices and the replacement of deep-rooted wood- and shrubland vegetation with shallow-rooted crops and perennial pasture grasses. Regional groundwater has been shown to rise on average by $25 \mathrm{~cm}_{\text {year }}{ }^{-1}$, but this is a stepped response, with water tables rising one to three metres during La Niña related wet phases such as 1974 to 1976 (Macumber 1991). Irrigation practices have elevated surface aquifers, bringing to the surface connate salts from Late Miocene marine incursions and residues from Plio-Pleistocene Lake Bungunnia associated with the Parilla Sand (Stephenson 1986). Evapoconcentration and the use of increasingly saline irrigation waters have reduced agricultural production and generated saline irrigation drainage waters which are returned to the Murray River and associated wetlands. Flushing of wetlands has declined because the frequency of peak flows has declined since the regulation of the Murray River (Walker and Thoms 1993).

Salinization management strategies have sacrificed some wetlands (e.g. Lake Ranfurley East) as saline drainage basins in order to spare more ecologically critical sites from saline 
input. In north-western Victoria more than twenty wetlands have been monitored for the Victorian Department of Natural Resources and Environment and the Community Implementation Groups of the Mallee Dryland, Sunraysia, Nyah to Border and the Nangiloc-Colignan Salinity Management Plans. This monitoring is to determine the response of terrestrial vegetation and wetlands to measures implemented for reducing dryland and irrigation salinization (Sluiter 1996a, 1996b, 1996c, 1996d).

This study reports on the changes to the epipelic (muddwelling) diatom assemblages between 1995 and 2000 in three of the monitored wetlands: Lake Hattah, Callander's Swamp and Psyche Bend Lagoon (Fig. 1). Many diatom species have been shown to have narrow ecological windows for salinity (Fritz et al. 1993; Cumming et al. 1995; Gasse et al. 1995; Gell 1997) and nutrient levels (Van Dam et al. 1994; Bennion 1994; Reid et al. 1995). As such, they are an ideal lifeform to biomonitor fluctuations in wetland salinity and nutrient status arising from groundwater, irrigated pasture, cropland and Murray River waters. These fluctuations occur under the pressures of desiccation in an environment where evaporation to precipitation ratios can exceed 10. Lake Hattah, usually the deepest of the three (3-4 m), lies within the Hattah-Kulkyne National Park and is a natural overflow lake linked to the Murray River via a distributory, or anabranch, known as Chalka Creek. Its northern and western margins are used as a camping area and are equipped with pit toilets. Callander's Swamp and Psyche Bend Lagoon are billabongs or meander cut-off lagoons in close contact with the Murray River. Callander's Swamp, usually the most shallow (1-2 m), is bordered on one side by a horticultural property and three residences and may periodically receive minor drainage water and domestic water inputs. In 1997 relatively fresh irrigation drainage water was diverted away from Psyche Bend Lagoon (depth usually 2-3 m), leaving its hydrological balance dominated by saline groundwater seepage for the remainder of the study period.

\section{Methods}

\section{Field sampling}

From September 1995 each site was visited four times each year in September/October, November/December and February/May, except when flooding precluded access (Callander's Swamp, May 1998). Also, no data are available from Lake Hattah because it was dry from May 1999 to at least September 2000 and Callander's Swamp was dry in February and May 2000. Single diatom samples were collected from within $2 \mathrm{~m}$ of the margin of each lake by scraping a spoon, or spatula, through the uppermost 2-3 mm of sediment lying at a depth of 30-50 $\mathrm{cm}$ underwater. It is believed that living, or recently dead, cells dominate such sediments. These samples were fixed in dilute ethanol before being sent to the University of Adelaide for preparation and analysis. Water samples $(500 \mathrm{~mL})$ were collected, at the time of the diatom sampling, from waters at the wetland margins at depths between 30 and $50 \mathrm{~cm}$ underwater. Water samples were frozen and sent to a National Association of Testing Authorities (Australia) (NATA) accredited laboratory for analysis of turbidity, total phosphorus (TP), total Kjeldahl nitrogen (TKN), nitrate, nitrite and total nitrogen (TN). Dissolved oxygen (DO), temperature, $\mathrm{pH}$ and conductivity were measured in the field at the time of diatom sampling using a Horiba U10 water quality checker (Kyoto, Japan). All conductivity values were corrected to $25^{\circ} \mathrm{C}$. The probes were held free standing at depths of 30 to $50 \mathrm{~cm}$. All sampling was done between $10 \mathrm{a} . \mathrm{m}$. and $4 \mathrm{p} . \mathrm{m}$.

\section{Laboratory analyses}

Epipelic samples were cleaned using standard dilute $\mathrm{HCl}$ and $\mathrm{H}_{2} \mathrm{O}_{2}$ treatments, then mounted on microscope slides (see Battarbee 1986; Gell 1997). At least 300 diatom valves were counted under 1000× magnification using either an Olympus BH-2 microscope (Tokyo, Japan) under bright field illumination, or more usually, a Zeiss Axiolab (Oberkochen, Germany) microscope under phase contrast. Diatoms were identified to species level and below following the comprehensive treatments of Krammer and Lange-Bertalot (1986-1991). Their nomenclature is used here but is updated to include changes, found in Round et al. (1990), and those summarized in Fourtanier and Kociolek (1999).

\section{Statistical analyses}

The counts of each diatom taxon were expressed as a percentage of the total valves counted and portrayed using the program TILIA (Grimm 1992). The relationships between the species assemblages and environmental variables were explored using Canonical Correspondence Analysis (CCA) in the program CANOCO (ter Braak 1988, 1990). After a preliminary analysis, the less common taxa, defined by those with $\mathrm{N} 2$ (Hill 1973) diversity values less than 4.0, were omitted and the program ran again. In both cases the default settings offered in CANOCO were selected and all taxa were given equal weighting. Owing to the frequency of nutrient measures that were below detection level, only TP and TN were included in the ordination analyses. Where values were missing, a value midway between the previous and subsequent measure was used.

\section{Results}

The results of the chemical analyses for each wetland are presented in Tables 1-3. Species assemblages are presented on TILIA diagrams (Figs 2, 4 and 6) with time since the beginning of the survey increasing down the y-axis. Plots of the CCA analyses are presented as Figs 3, 5 and 7.

\section{Callander's Swamp}

Shortly after it received inflow from the Murray River in early spring 1996, the conductivity of Callander's Swamp water generally remained between 100 and $300 \mu \mathrm{S} \mathrm{cm}^{-1} \mathrm{~cm}^{-1}$ (Table 1). At these times $\mathrm{pH}$ was generally between 7 and 8 , with and turbidity and nutrient levels comparatively low. Callander's Swamp tended to be dry from late summer to winter after the connection to the Murray River was severed. This led to increased conductivities, $\mathrm{pH}$ values as high as 9.52 and elevated turbidity and nutrient levels, possibly owing to increased sediment entrainment under shallow conditions. At least on one occasion (February 1998) Callander's Swamp was eutrophic. The total nitrogen was usually present only as TKN. Temperature ranged from $10.5^{\circ} \mathrm{C}$, in August 1997 , to a maximum of $31.0^{\circ} \mathrm{C}$, in December 1999. The Swamp twice dried out completely, between February 1998 and September 1999 and again after December 1999. 


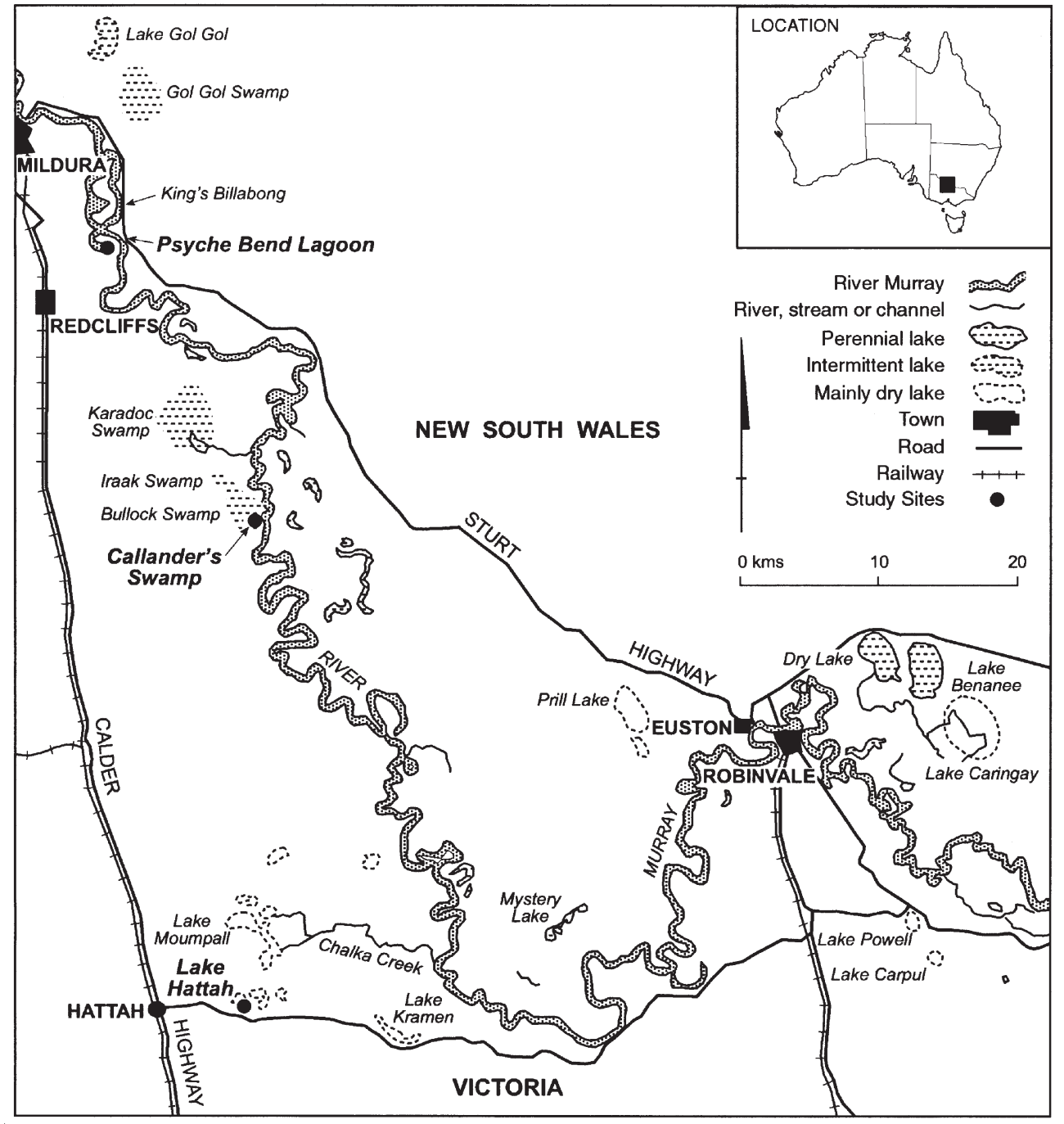

Fig. 1. Eastern section of the region monitored under four Salinity Management Plans.

The summary diagram of the common diatom species identified from samples collected at Callander's Swamp reveals considerable seasonal variation (Fig. 2). The spring and summer samples from 1995 and 1996 were dominated by Aulacoseira species, presumably deriving from input originating from the high biomass of these taxa in modern Murray River water (Hotzel and Croome 1996). Evapoconcentration occurring through to May 1996 saw a sequential replacement of this river plankton by Cyclotella meneghiniana, Nitzschia agnita and Tryblionella levidensis (all in February 1996) and then the brackish water form Tryblionella hungarica when conductivity values reached a maximum of $2430 \mu \mathrm{S} \mathrm{cm}^{-1}$ in May 1996. Flooding from the Murray River in spring 1996 induced a return to an Aulacoseira-dominated diatom flora. This showed a sequence where Aulacoseira granulata ceded dominance to Aulacoseira ambigua after river input was cut off. A community dominated by Fragilaria capucina and Hippodonta capitata ultimately replaced these, in August 1997. The shift to the eutraphentic (preferring eutrophic waters) taxa Stephanodiscus parvus and Eolimna subminuscula by December 1997 and Nitzschia palea by February 1998 is consistent with evapoconcentration of salts and nutrients but not to a level where brackish taxa are likely to predominate (Van Dam et al. 1994). The Swamp partially refilled after a small flood in winter-spring 1999. Although a proportionally small number of Aulacoseira species were counted, the flora comprised mainly eutraphentic forms such as Achnanthes exigua and Luticola mutica, in September 1999 and Cyclotella meneghiniana, Gomphonema parvulum and Nitzschia palea, in December 1999. Luticola mutica is an aerophilous form (Gasse 1986) capable of growing out of water on wet surfaces and so may have been introduced with eroded sediments when refilling occurred. 
Table 1. Water chemistry data from Callander's Swamp (Sep. 1995-May 2000)

n.d., Not detectable; dates are given in the format: day.month.year.

\begin{tabular}{lcccccccccc}
\hline Date & $\mathrm{pH}$ & $\begin{array}{c}\text { Conductivity } \\
\left(\mu \mathrm{S} \mathrm{cm}^{-1}\right)\end{array}$ & $\begin{array}{c}\text { Turbidity } \\
(\mathrm{NTU})\end{array}$ & $\begin{array}{c}\mathrm{DO} \\
\left(\mathrm{mg} \mathrm{L}^{-1}\right)\end{array}$ & $\begin{array}{c}\text { Temperature } \\
\left({ }^{\circ} \mathrm{C}\right)\end{array}$ & $\begin{array}{c}\text { Total P } \\
\left(\mathrm{mg} \mathrm{L}^{-1}\right)\end{array}$ & $\begin{array}{c}\mathrm{TKN} \\
\left(\mathrm{mg} \mathrm{L}^{-1}\right)\end{array}$ & $\begin{array}{c}\text { Nitrate } \\
\left(\mathrm{mg} \mathrm{L}^{-1}\right)\end{array}$ & $\begin{array}{c}\text { Nitrite } \\
\left(\mathrm{mg} \mathrm{L}^{-1}\right)\end{array}$ & $\begin{array}{c}\text { Total N } \\
\left(\mathrm{mg} \mathrm{L}^{-1}\right)\end{array}$ \\
\hline 19.9 .95 & - & 260 & 19 & - & 18.7 & $<0.01$ & $<0.20$ & $<0.10$ & $<0.1$ & 0.2 \\
17.11 .95 & 8.22 & 326 & 312 & 7.64 & 23.4 & 0.10 & 1.2 & $<0.10$ & $<0.1$ & 1.2 \\
3.3 .96 & 9.52 & 1360 & 307 & 12.49 & 23.1 & 0.20 & n.d. & 0.10 & n.d. & 0.1 \\
7.5 .96 & 9.03 & 2430 & 110 & 14.9 & 18.0 & 0.40 & 3.8 & 0.20 & n.d. & 4.0 \\
8.10 .96 & 7.56 & 192 & 46 & 8.79 & 21.4 & 0.08 & 0.5 & n.d. & n.d. & 0.5 \\
3.12 .96 & 7.63 & 138 & 10 & 5.65 & 20.7 & 0.10 & 0.8 & n.d. & n.d. & 0.8 \\
28.2 .97 & 9.21 & 239 & 85 & 10.18 & 25.0 & 0.20 & 2.4 & n.d. & n.d. & 2.4 \\
6.5 .97 & 7.67 & 283 & 54 & 8.36 & 16.5 & 0.14 & 1.8 & n.d. & n.d. & 1.8 \\
28.8 .97 & 7.48 & 277 & 312 & 7.97 & 10.5 & 0.08 & 2.3 & 0.05 & n.d. & 2.35 \\
5.12 .97 & 8.68 & 484 & 515 & 10.5 & 29.3 & 0.20 & 2.8 & 0.18 & 0.13 & 3.11 \\
24.2 .98 & 9.29 & 1410 & 444 & 15.86 & 29.5 & 0.48 & 8.6 & n.d. & n.d. & 8.6 \\
14.5 .98 & No & Access & & & & & & & & $<0.005$ \\
24.9 .99 & 7.03 & 339 & 5 & 3.91 & 24.6 & 0.16 & 1.3 & 0 & $<23$ \\
3.12 .99 & 7.00 & 530 & 17.5 & 5.4 & 31.0 & 0.36 & 2.2 & 0 & $<0.005$ & 2.22 \\
27.2 .00 & & Dry & & & & & & & & \\
13.5 .00 & & Dry & & & & & & & &
\end{tabular}

In Fig. $3 a$, axis 1 is negatively correlated to conductivity and relates to a gradient reflecting evapoconcentration after flooding. To the lower left are dilute samples reflecting river inputs in spring 1995 (November), spring 1996 (October and December) and winter 1997 (August). The early 1996 samples (March and May), taken when swamp conductivity exceeded $1400 \mu \mathrm{S} \mathrm{cm}^{-1}$, plot to the right. Axis 2 relates to nutrient levels, with samples taken while the lake was eutrophic (February and December) plotting towards the top of the diagram in accord with the TP and $\mathrm{TN}$ vectors (Fig. 3b). The lake was also eutrophic in May 1996 and its position to the right of the plot reflects the strength of the control of salinity on diatom assemblages. The species assemblages (Fig. $3 c$ ) conform predictably to the Fig. $3 b$

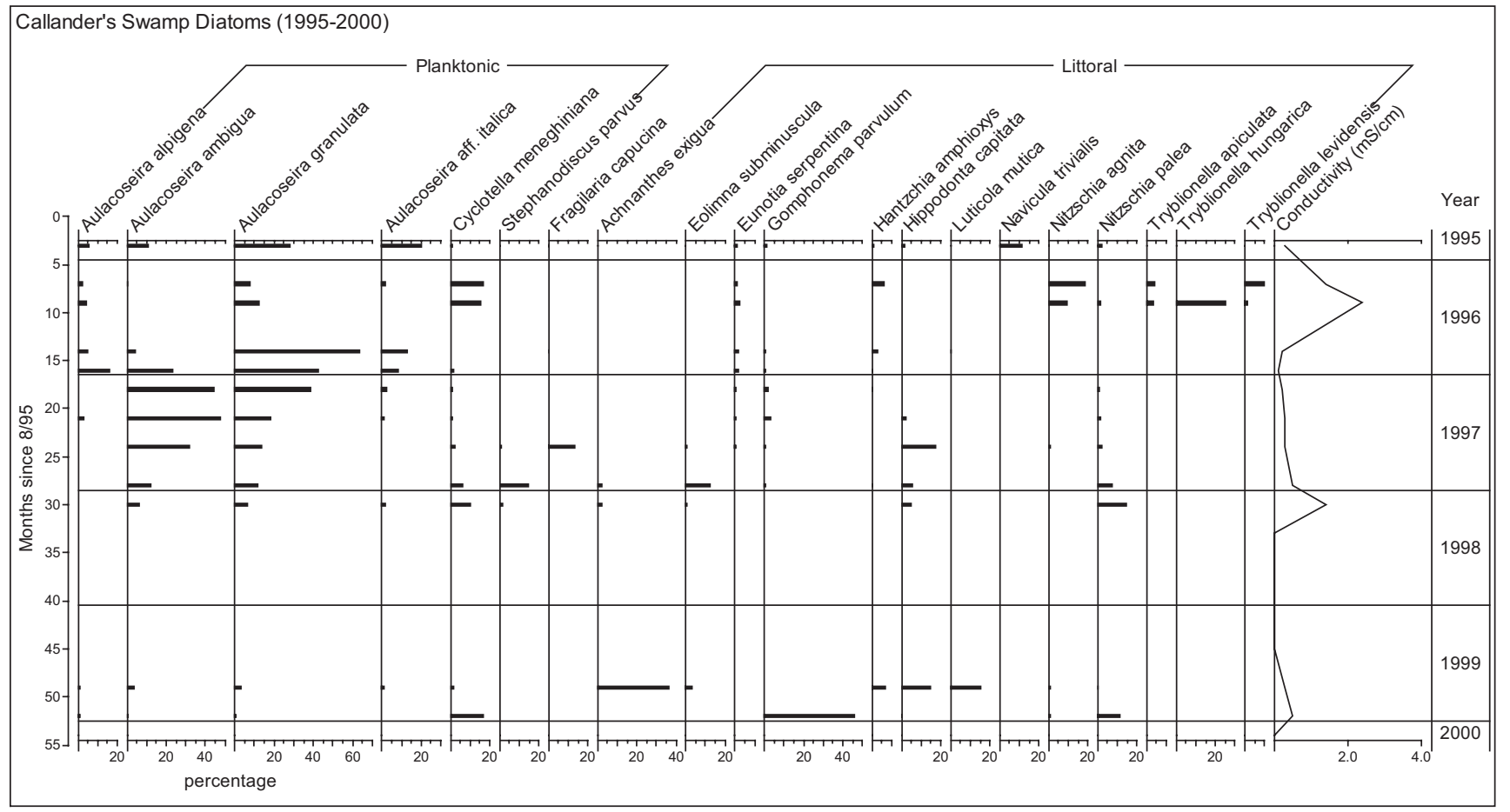

Fig. 2. Variations in assemblages of common diatom taxa at Callander's Swamp (Nov. 1995 to Dec. 1999). NB: Callander's Swamp was dry from mid-1998 to mid-1999 and after December 1999; access was denied due to flooding in spring 1996. 


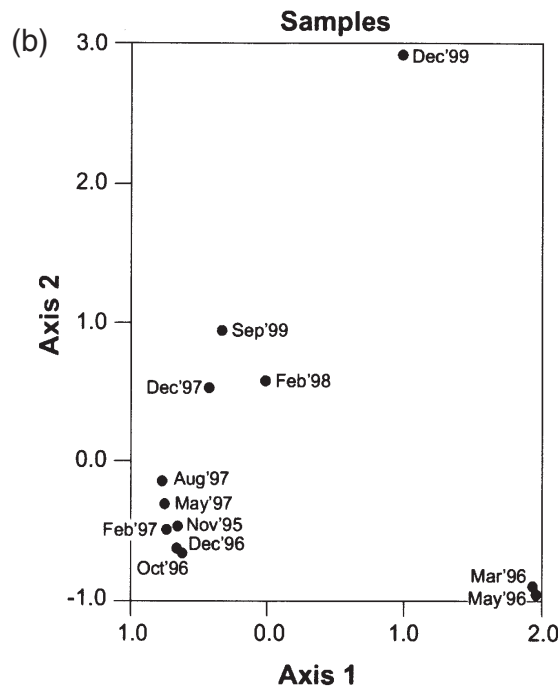

\section{CALLANDER'S SWAMP}

\section{.0}
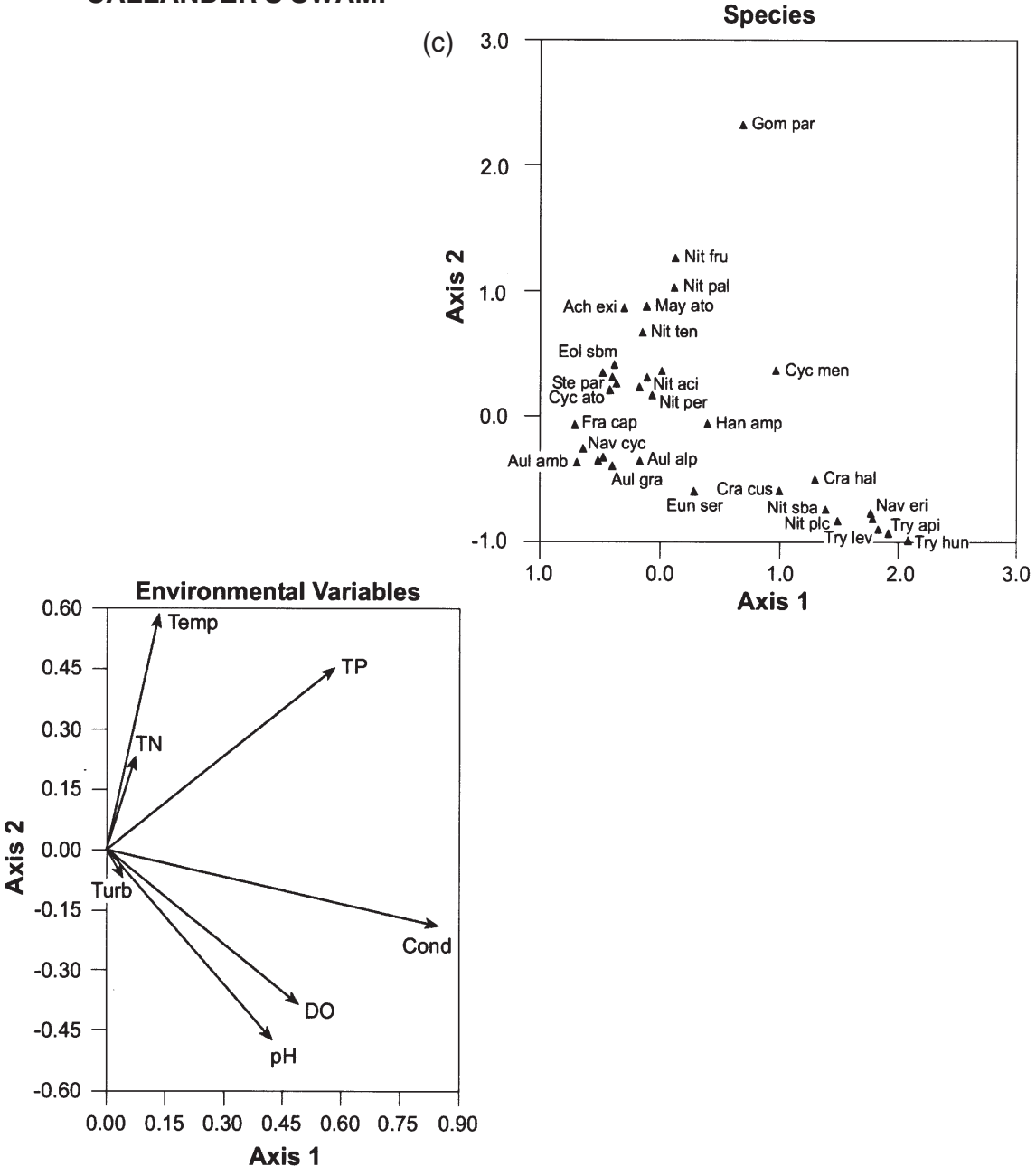

(a)

Axis 1

Fig. 3. Constrained ordination of diatom assemblages and physico-chemical data from Callander's Swamp (Nov. 1995 to Dec. 1999). Ach exi = Achanthes exigua; Aul alp = Aulacoseira alpigena $($ syn. A. subborealis $) ;$ Aul gra = Aulaceseira granulata $;$ Cra cus = Craticula cuspidata $;$ Cra hal $=$ Craticula halophila $;$ Cyc ato = Cyclotella atomus; Cyc men =Cyclotella meneghiniana $;$ Eol sbm = Eolimna subminuscula $;$ Eun ser $=$ Eunotia serpentina $;$ Fra cap = Fragilaria capucina $;$ Gom par = Gomphonema parvulum; Han amp = Hantzschia amphioxys; May ato = Mayamaea atomus; Nav cyc $=$ Navicula cryptocephala $; \mathrm{Nav}$ eri $=$ Navicula erifuga $; \mathrm{Nit}$ aci $=$ Nitzschia acicularis $; \mathrm{Nit}$ fru $=$ Nitzschia frustulum; $\mathrm{Nit}$ pal $=$ Nitzschia palea $;$ Nit plc = Nitzschia paleaceae $;$ Nit per = Nitzschia perminuta $; \mathrm{Nit}$ sba = Nitzschia subacicularis $;$ Nit ten = Nitzschia palea var. tenuirostris; Ste par $=$ Stephanodiscus parvus; Try api $=$ Tryblionella apiculata $;$ Try hun $=$ Tryblionella hungarica $;$ Try lev $=$ Tryblionella levidensis.

vectors, with brackish water taxa (e.g. Craticula halophila, Tryblionella species) plotting to the right, eutraphentic taxa (e.g. Eolimna subminuscula, Gomphonema parvulum, Mayamaea atomus, Nitzschia frustulum, Nitzschia palea) to the top, and taxa that form part of the river plankton plot (e.g. Aulacoseira alpigena, Aulacoseira ambigua, Aulacoseira granulata) to the lower left. Cyclotella meneghiniana, a facultative nitrogen heterotroph (Van Dam et al. 1994) tolerant of elevated salinity levels (Gell 1997), plots between the conductivity and nutrient vectors.

\section{Lake Hattah}

After the filling phase in spring 1995, when the $\mathrm{pH}$ was 6.5, the waters of Lake Hattah were fresh $\left(<500 \mu \mathrm{S} \mathrm{cm}^{-1}\right)$ for most of the surveys until December 1997, when drying concentrated salts and nutrients (Table 2). The $\mathrm{pH}$ values through this period were generally between 8.0 and 8.3. Through this period the concentration of TP was low to moderate although TN, principally as TKN, was moderate to high. From the summer of 1997 and 1998 conductivities exceeded $1000 \mu \mathrm{S} \mathrm{cm}^{-1}$ and $\mathrm{pH}$ exceeded 8.5, the turbidity increased to a peak of 594 NTU and the lake became eutrophic. Temperatures ranged from $12.2^{\circ} \mathrm{C}$ (August 1997) to $27.0^{\circ} \mathrm{C}$ (December 1996). Lake Hattah remained dry after autumn 1999.

Input of Murray River water via Chalka Creek preceded the establishment of an Aulacoseira alpigena, Aulacoseira granulata and Nitzschia perinea assemblage in September 
Table 2. Water chemistry data from Lake Hattah (Sep. 1995-May 2000) n.d., Not detectable; dates are given in the format: day.month.year.

\begin{tabular}{|c|c|c|c|c|c|c|c|c|c|c|}
\hline Date & $\mathrm{pH}$ & $\begin{array}{l}\text { Conductivity } \\
\left(\mu \mathrm{S} \mathrm{cm}^{-1}\right)\end{array}$ & $\begin{array}{l}\text { Turbidity } \\
\text { (NTU) }\end{array}$ & $\begin{array}{c}\mathrm{DO} \\
\left(\mathrm{mg} \mathrm{L}^{-1}\right)\end{array}$ & $\begin{array}{c}\text { Temperature } \\
\left({ }^{\circ} \mathrm{C}\right)\end{array}$ & $\begin{array}{c}\text { Total P } \\
\left(\mathrm{mg} \mathrm{L}^{-1}\right)\end{array}$ & $\begin{array}{c}\text { TKN } \\
\left(\mathrm{mg} \mathrm{L}^{-1}\right)\end{array}$ & $\begin{array}{l}\text { Nitrate } \\
\left(\mathrm{mg} \mathrm{L}^{-1}\right)\end{array}$ & $\begin{array}{l}\text { Nitrite } \\
\left(\mathrm{mg} \mathrm{L}^{-1}\right)\end{array}$ & $\begin{array}{l}\text { Total N } \\
\left(\mathrm{mg} \mathrm{L}^{-1}\right)\end{array}$ \\
\hline 22.9 .95 & 6.5 & 340 & 22 & - & 21.7 & $<0.01$ & 0.9 & $<0.01$ & $<0.1$ & 0.9 \\
\hline 20.11 .95 & 8.07 & 396 & 118 & 7.36 & 22.4 & $<0.01$ & $<0.2$ & $<0.01$ & $<0.1$ & $<0.2$ \\
\hline 2.3 .96 & 8.31 & 541 & 158 & 6.84 & 19.5 & 0.15 & 4.7 & 0.8 & ND & 5.5 \\
\hline 7.5.96 & 8.00 & 640 & 170 & 8.1 & 16.0 & 0.17 & 2.0 & 1.2 & n.d. & 3.2 \\
\hline 6.10 .96 & 7.84 & 344 & 59 & 7.51 & 15.9 & 0.13 & 1.0 & 0.09 & n.d. & 1.009 \\
\hline 6.12 .96 & 8.16 & 280 & 75 & 8.05 & 27.0 & 0.14 & 1.0 & 0.05 & n.d. & 1.05 \\
\hline 27.2 .97 & 8.04 & 422 & 122 & 6.30 & 23.6 & 0.09 & 1.3 & n.d. & n.d. & 1.3 \\
\hline 6.5 .97 & 8.08 & 466 & 84 & 10.30 & 16.2 & 0.16 & 1.2 & n.d. & n.d. & 1.2 \\
\hline 27.8 .97 & 8.47 & 493 & 68 & 11.8 & 12.2 & 0.04 & 1.0 & n.d. & n.d. & 1.0 \\
\hline 15.12 .97 & 7.88 & 631 & 176 & 7.70 & 22.4 & 0.06 & 1.3 & n.d. & n.d. & 1.3 \\
\hline 23.2 .98 & 8.52 & 824 & 264 & 9.80 & 20.4 & 0.13 & 1.6 & n.d. & n.d. & 1.6 \\
\hline 15.5 .98 & 9.01 & 1080 & 195 & 11.7 & 22.2 & 0.19 & 1.9 & n.d. & n.d. & 1.9 \\
\hline 3.9 .98 & 8.55 & 1150 & 325 & 11.34 & 13.4 & 0.574 & 4.05 & 0 & $<0.005$ & 4.05 \\
\hline 10.11 .98 & 8.53 & 1420 & 594 & 9.87 & 21.8 & 0.808 & 6.96 & 0 & $<0.005$ & 6.96 \\
\hline 7.2 .99 & 8.68 & 3740 & 235 & 10.29 & 17.1 & 1.18 & 11.1 & 0 & $<0.005$ & 11.1 \\
\hline 20.5 .99 & & Dry & & & & & & & & \\
\hline 28.9 .99 & & Dry & & & & & & & & \\
\hline 3.12 .99 & & Dry & & & & & & & & \\
\hline 4.2 .00 & & Dry & & & & & & & & \\
\hline 13.5 .00 & & Dry & & & & & & & & \\
\hline
\end{tabular}

1995 (Fig. 4). This was sequentially replaced by (facultative) planktonic assemblages dominated by Staurosira construens var. subsalina in November 1995, Aulacoseira ambigua, Aulacoseira granulata and Staurosirella pinnata in February 1996 and Pseudostaurosira brevistriata and Staurosira construens forma venter by May 1996. The brackish benthic forms Amphora coffeaeformis var. borealis, Amphora cognata and Amphora veneta reflect the elevated conductivities, albeit only as high as $640 \mu \mathrm{S} \mathrm{cm}{ }^{-1}$, by May 1996. The freshwater planktonic form Melosira varians returned by December 1996 with a dilution of Lake waters, after which Aulacoseira alpigena, Aulacoseira granulata and Cyclotella stelligera reappeared. Hattah Lake then commenced a period of progressive evapoconcentration, with desiccation occurring by autumn 1999. The coincident increase in lake water conductivity and nutrient concentrations saw a sequential shift in diatom assemblage to Pseudostaurosira brevistriata and Staurosira construens var. subsalina from mid-1997 to February 1998, with a small increase in Aulacoseira alpigena and Aulacoseira granulata in December 1997. Staurosira construens forma venter then dominated the diatom flora, to be complemented by the benthic Planothidium delicatulum in September 1998, ultimately it appeared with a mixed planktonic assemblage made up mainly of Aulacoseira alpigena, Aulacoseira granulata, Cyclostephanos dubius and Cyclotella meneghiniana. Several benthic Nitzschia and Tryblionella species became apparent in the February 1999 sample when the Lake was at its shallowest, most saline and eutrophic.
The constrained ordination identifies dissolved oxygen as the strongest variable on axis 1 (Fig. 5). This arises largely as three outlying samples of quite unique assemblages occurred when DO values were lower. In December 1996 an assemblage dominated by Melosira varians coincided with high temperatures. Also, the high total nitrogen-low conductivity conditions of March and May 1996 coincided with assemblages dominated by Staurosirella pinnata, Amphora coffeaeformis var. borealis and Amphora cognata. In no other sample did any of these four taxa attain proportional abundance values in excess of $6 \%$. The cluster of samples and species around the origin represent relatively fresh conditions and include the river-borne plankton Aulacoseira granulata and Cyclotella stelligera. The four surveys made before the lake dried completely plot to the left and correlate with the turbidity, conductivity and $\mathrm{pH}$ vectors. These samples also accord with the DO vector (Fig. 5b), having higher DO values perhaps owing to shallow water conditions, low temperatures and high algal productivity. These coincide with the eutraphentic taxa Cyclotella meneghiniana, Cyclostephanos dubius and Nitzschia palea and the brackish form Planothidium delicatulum.

\section{Psyche Bend Lagoon}

From September 1995 to December 1996 the waters of Psyche Bend Lagoon remained oligo- to mesosaline (Table 3). Drying during the summer of 1995/96 produced elevated salinities that were diluted by Murray River input in spring 1996. This, like the filling phase in spring 1995, acted 


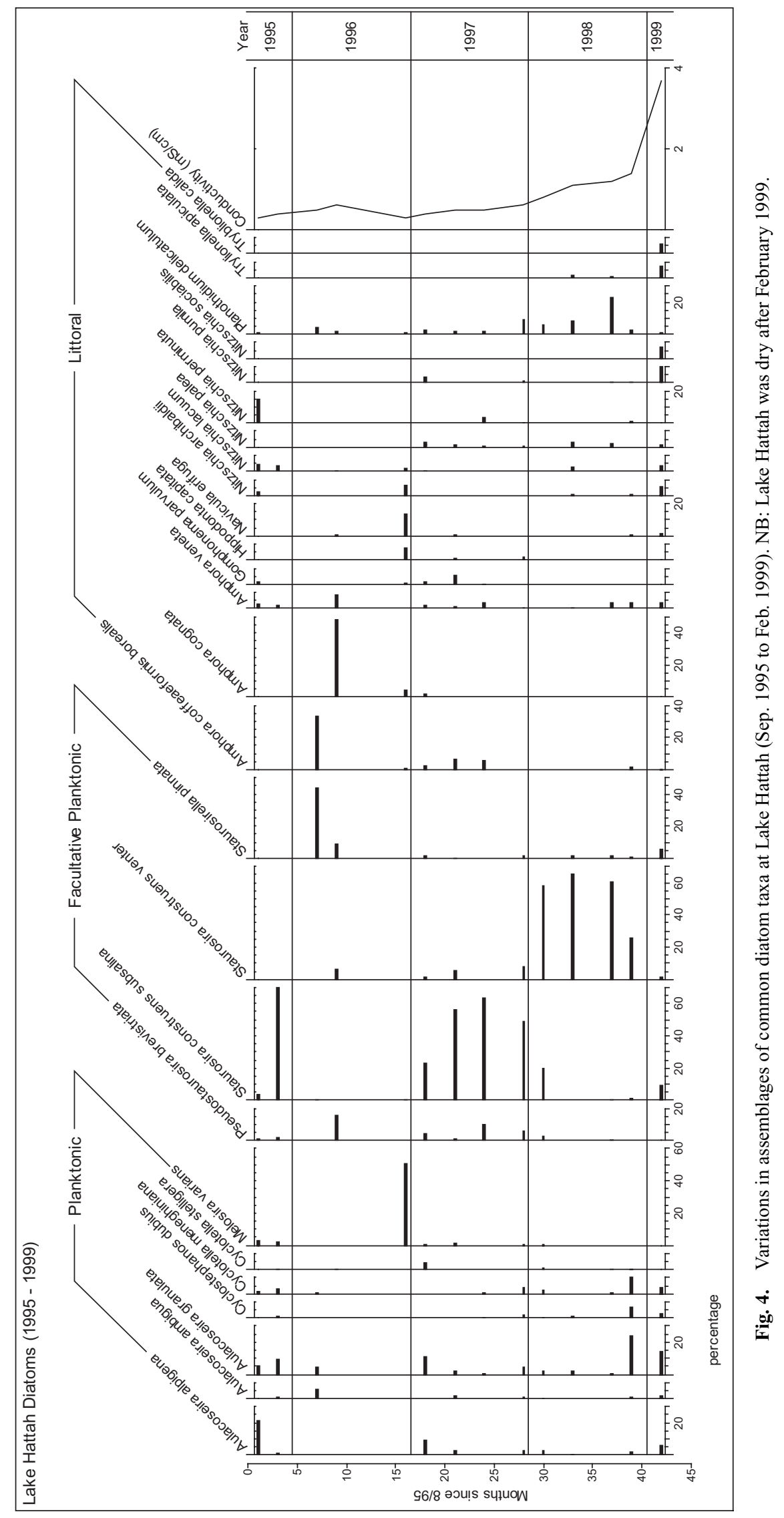




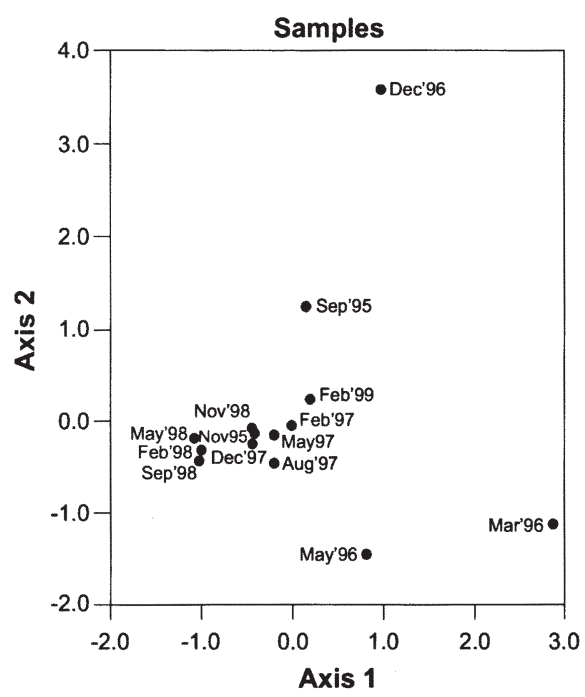

LAKE HATTAH

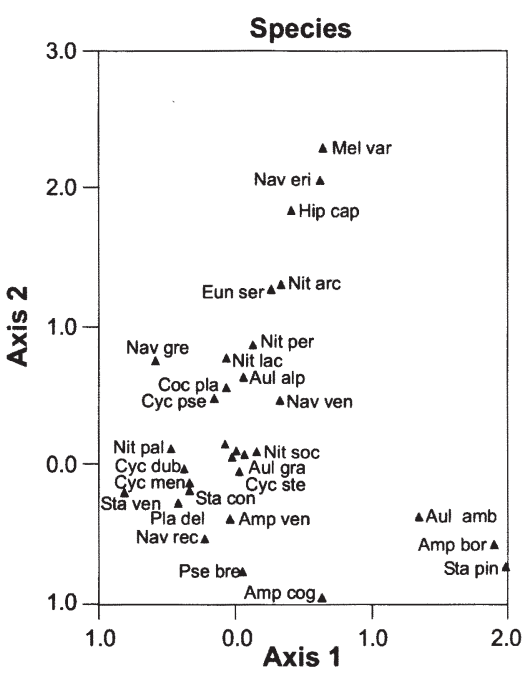

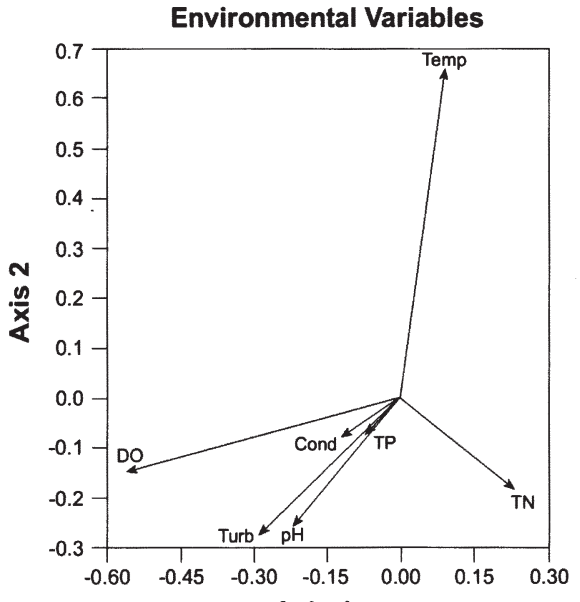

Axis 1

Fig. 5. Constrained ordination of diatoms assemblages and physico-chemical data from Lake Hattah (Sep. 1995 to Feb. 1999). Amp bor $=$ Amphora coffeaeformis var. borealis; Amp $\operatorname{cog}=$ Amphora cognata; Amp ven = Amphora veneta; Aul alp = Aulacoseira alpigena $($ syn. A. subborealis); Aul amb = Aulacoseira ambigua $;$ Aul gra = Aulaceseira granulata $;$ Coc pla = Cocconeis placentula $;$ Cyc men $=$ Cyclotella meneghiniana $;$ Cyc pse $=$ Cyclotella pseudostelligera $;$ Cyc ste $=$ Cyclotella stelligera $;$ Cys dub $=$ Cyclostephanos dubius; Eun $\mathrm{ser}=$ Eunotia serpentina $;$ Hip cap = Hippodonta capitata $; \mathrm{Mel}$ var = Melosira varians; $\mathrm{Nav}$ eri = Navicula erifuga $;$ Nav gre = Navicula gregaria $; \mathrm{Nav}$ rec $=$ Navicula recens $;$ Nav ven $=$ Navicula veneta $;$ Nit arc $=$ Nitzschia archibaldii $;$ Nit lac $=$ Nitzschia lacuum; Nit pal $=$ Nitzschia palea $;$ Nit per $=$ Nitzschia perminuta $;$ Nit $\operatorname{soc}=$ Nitzschia sociabilis. Pla del $=$ Planothidium delicatulum. Pse bre $=$ Pseudostaurosira brevistriata $;$ Sta con = Staurosira construens var. construens; Sta pin = Staurosirella pnnata $;$ Sta ven $=$ Staurosira construens forma venter.

to reduce total nitrogen. Unlike the other sites the fresh phases produced the most turbid waters, possibly as the high salt concentrations in the shallow phases acted to remove suspended particles. Total phosphorus values remained below $0.01 \mathrm{mg} \mathrm{L}^{-1}$. Thereafter salinity levels increased substantially, owing to evapoconcentration, and the diversion of saline irrigation-drainage waters into the Lagoon. In the space of ten weeks, this increased the $\mathrm{pH}$ almost one unit, doubled the TP and trebled the TN values. Total nitrogen concentrations remained above $1.0 \mathrm{mg} \mathrm{L}^{-1}$ until it dried in Autumn 1999. By May 1997, the lagoonal conductivity had exceeded $20000 \mu \mathrm{S} \mathrm{cm}-1$ and remained above that value through the study period, usually being $\sim 50000 \mu \mathrm{S} \mathrm{cm}^{-1}$. By the summer of 1998/99 the lagoon had become eutrophic and remained so until the end of the survey. Water temperature ranged from a low of $13.9^{\circ} \mathrm{C}$ in May 1999 to a maximum of $32.8^{\circ} \mathrm{C}$ in February 1997.

The September 1995 assemblage at Psyche Bend Lagoon was dominated by the benthic taxon Navicula spicula. This was despite recent inflow from the Murray River providing for a planktonic diatom assemblage dominated by Aulacoseira ambigua and Aulacoseira granulata and the facultative planktonic Staurosira construens (Fig. 6). By November 1995, the facultatitive planktonic Fragilariaceae- 
Table 3. Water chemistry data from Psyche Bend Lagoon (Sep. 1995-May 2000)

n.d., Not detectable; dates are given in the format: day.month.year.

\begin{tabular}{lcccccccccc}
\hline Date & $\mathrm{pH}$ & $\begin{array}{c}\text { Conductivity } \\
\left(\mu \mathrm{S} \mathrm{cm}^{-1}\right)\end{array}$ & $\begin{array}{c}\text { Turbidity } \\
(\mathrm{NTU})\end{array}$ & $\begin{array}{c}\mathrm{DO} \\
\left(\mathrm{mg} \mathrm{L}^{-1}\right)\end{array}$ & $\begin{array}{c}\text { Temperature } \\
\left({ }^{\circ} \mathrm{C}\right)\end{array}$ & $\begin{array}{c}\text { Total P } \\
\left(\mathrm{mg} \mathrm{L}^{-1}\right)\end{array}$ & $\begin{array}{c}\mathrm{TKN} \\
\left(\mathrm{mg} \mathrm{L}^{-1}\right)\end{array}$ & $\begin{array}{c}\text { Nitrate } \\
\left(\mathrm{mg} \mathrm{L}^{-1}\right)\end{array}$ & $\begin{array}{c}\text { Nitrite } \\
\left(\mathrm{mg} \mathrm{L}^{-1}\right)\end{array}$ & $\begin{array}{c}\text { Total N } \\
\left(\mathrm{mg} \mathrm{L}^{-1}\right)\end{array}$ \\
\hline 18.9 .1995 & - & 2150 & 155 & - & 19.6 & $<0.01$ & $<0.2$ & $<0.1$ & $<1$ & 1.20 \\
17.11 .95 & 8.52 & 4990 & 72 & 11.7 & 26.8 & $<0.01$ & $<0.2$ & 0.4 & $<1$ & 1.60 \\
26.2 .96 & 9.24 & 5550 & 38 & 9.37 & 27.3 & 0.07 & 2.0 & 0.2 & n.d. & 2.20 \\
9.5 .96 & 9.0 & 9000 & 40 & 12.3 & 18.7 & 0.07 & 1.4 & n.d. & n.d. & 1.40 \\
3.10 .96 & 8.39 & 2555 & 40 & 10.89 & 17.8 & 0.09 & 0.9 & 0.05 & n.d. & 0.95 \\
3.12 .96 & 8.24 & 1350 & 70 & 7.5 & 22.0 & 0.09 & 0.9 & 0.03 & n.d. & 0.93 \\
22.2 .97 & 9.16 & 16300 & 52 & 10.17 & 32.8 & 0.21 & 3.0 & n.d. & n.d. & 3.00 \\
4.5 .97 & 8.41 & 24500 & 12 & 1.36 & 17.4 & 0.26 & 2.9 & 0.04 & 0.02 & 2.96 \\
28.8 .97 & 8.87 & 21400 & 34 & 14.22 & 12.8 & 0.12 & 1.7 & n.d. & 0.01 & 1.71 \\
12.12 .97 & 8.25 & 32700 & 7 & 11.6 & 30.2 & 0.08 & 1.8 & n.d. & n.d. & 1.80 \\
19.2 .98 & 8.68 & 37800 & 41 & 17.58 & 25.7 & 0.07 & 2.2 & 0.01 & n.d. & 2.21 \\
13.5 .98 & 9.51 & 45100 & 7 & 19.99 & 18.9 & 0.04 & 1.1 & n.d. & n.d. & 1.10 \\
3.9 .98 & 8.87 & 46850 & 10 & 16.57 & 18.3 & 0.097 & 2.15 & 0.00 & $<0.005$ & 2.15 \\
10.11 .98 & 9.26 & 48300 & 12 & 13.64 & 22.7 & 0.075 & 2.92 & 0.00 & $<0.005$ & 2.92 \\
6.2 .99 & 8.24 & 56800 & 44 & 6.84 & 29.5 & 0.201 & 3.44 & 0.101 & 0.027 & 3.568 \\
29.5 .99 & 8.63 & 57000 & 11 & 7.7 & 13.9 & 0.201 & 3.92 & 0.00 & $<0.005$ & 3.92 \\
25.9 .99 & 8.34 & 54166 & 15 & 8.91 & 20.2 & 0.162 & 3.60 & 0.001 & $<0.005$ & 3.601 \\
3.12 .99 & 8.2 & 36000 & 9.5 & 7.1 & 26.5 & 0.293 & 4.68 & 0.00 & $<0.005$ & 4.68 \\
27.22 .00 & 8.35 & 25933 & 35 & 19.99 & 28.0 & 0.282 & 6.56 & 0.751 & 0.007 & 7.318 \\
13.5 .00 & 8.88 & 46100 & 60 & 9.55 & 17.2 & 0.241 & 5.10 & 0.00 & $<0.005$ & 5.10 \\
\hline
\end{tabular}

types (Pseudostaurosira brevistriata, Staurosira construens and Staurosirella pinnata) dominated the assemblage, to be replaced by the brackish species Navicula spicula in February and May 1996. Another brackish water taxon, Tryblionella apiculata, was a common element as the Lagoon became more saline in autumn. In October 1996, flooding saw another pulse of Aulacoseira species into Psyche Bend Lagoon. The return to a Staurosira construens and Navicula spicula-dominated community in February followed a diverse assemblage seen in December 1996, in which 49 taxa were identified. As conductivities rose above $15000 \mu \mathrm{S} \mathrm{cm} \mathrm{cm}^{-1}$ by February, attaining $45000 \mu \mathrm{S} \mathrm{cm} \mathrm{cm}^{-1}$ by May 1998 and a maximum of $57000 \mu \mathrm{S} \mathrm{cm}^{-1}$ in May 1999, the diatom assemblage became increasingly dominated by brackish (e.g. Chaetoceros muelleri, Gyrosigma acuminatum, Navicella pusilla, Nitzschia microcephala) and saline (e.g. Amphora coffeaeformis, Navicula incertata, Navicula salinicola, Nitzschia hybrida, Staurophora salina) taxa. Despite conductivities in excess of $56000 \mu \mathrm{S} \mathrm{cm}^{-1}$, the typically freshwater to oligosaline Pseudostaurosira brevistriata, Staurosira construens and Staurosirella pinnata were among the common taxa in February and May 1999. A substantial freshening in the waters of the billabong to $25993 \mu \mathrm{S} \mathrm{cm}{ }^{-1}$ from a small flood in spring 1999 was accompanied by the return of Aulacoseira granulata, albeit in small numbers. These may have been introduced in the fresh floodwaters and may not necessarily have persisted or grown in such high conductivities.

Vectors parallel to axis 1 on the ordination plots (Fig. 7) reveal conductivity to be the strongest variable, and strongly, negatively, correlated with turbidity. All samples taken after February 1997, when Psyche Bend Lagoon conductivities exceeded $20000 \mu \mathrm{S} \mathrm{cm}^{-1}$, are to the left of the samples plot, and all those prior to May 1997 plot to the right. Axis 1 on the species plot strongly reflects the salinity preferences of the taxa identified. Furthest to the right are freshwater taxa (Aulacoseira species, Gomphonema parvulum, Navicula cryptocephala) and then small Fragilariaceae. Of the latter, the plot reveals a sequence of taxa across a gradient of increasing salinity gradient consisting of; Staurosira construens var. construens, Staurosirella pinnata, Pseudostaurosirella brevistriata, Staurosira construens forma venter, and Staurosira elliptica. Brackish taxa (e.g. Gyrosigma acuminatum, Navicula perminuta, Rhopalodia brebissonii) plot around -0.5 on axis 1 and taxa with known affinities (see Sonneman et al. 2000) for high salinity (e.g. Amphora coffeaeformis, Navicula salinicola, Nitzschia hybrida, Proshkinia bulnheimii, Staurophora salina) have axis 1 values approaching -1.0 .

The nutrient values, TP and TN are strong covariables and appear directly correlated with conductivity, probably owing to evapoconcentration. However, several taxa that are known to prefer eutrophic conditions (Anomoeoneis sphaerophora, Cyclotella meneghiniana, Gomphonema parvulum and Nitzschia palea) have positive axis 1 values, revealing a strong intolerance for such high salinity levels. Axis two reveals a secondary gradient correlated to $\mathrm{pH}$ and, to a lesser extent, temperature. That they increase in opposite directions suggests that the most alkaline conditions coincided with the cooler months. Most of the surveys where $\mathrm{pH}$ exceeded 


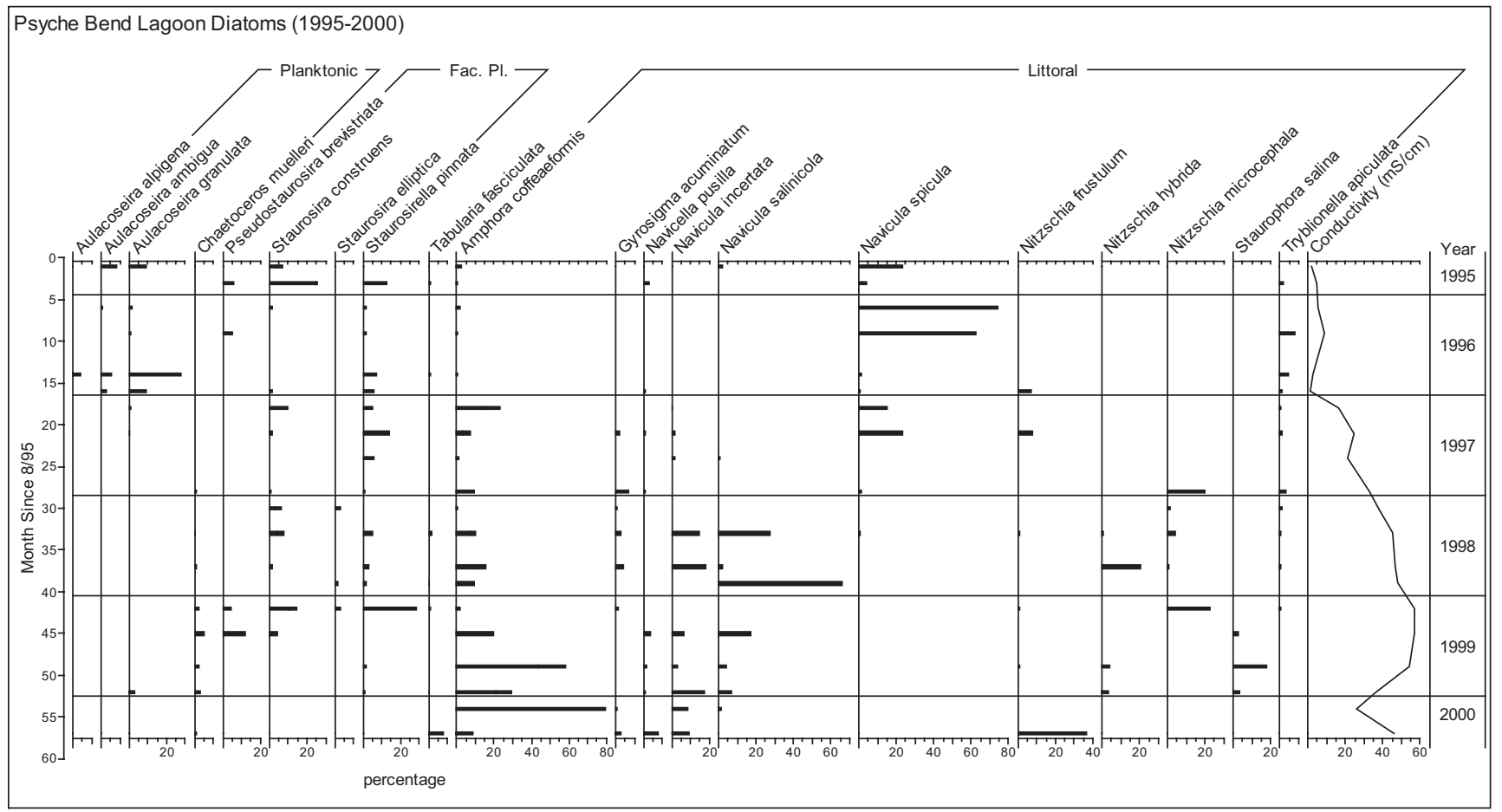

Fig. 6. Variations in assemblages of common diatom taxa at Psyche Bend Lagoon (Sep. 1995 to Dec. 1999).

8.8 plot in the upper half of the samples diagram. Known alkaliphilous taxa (e.g. Anomoeoneis sphaerophora, Navicella pusilla, Navicula spicula, Tabularia fasciculata) also plot in the upper half of the diagram.

\section{Discussion}

The records of the diatom assemblages from the three selected river-connected wetlands reveal a link between Murray River water input and elevated relative abundance values of Aulacoseira species, mostly Aulacoseira granulata. Aulacoseira-dominated floras arose after Murray River inflow at Callander's Swamp, before November 1995 and October 1996, at Lake Hattah, before November 1995 and February 1997 and at Psyche Bend Lagoon, before September 1995 and October 1996. Furthermore, small flooding events generated concomitantly small $(\sim 2 \%)$ pulses of A. granulata in Psyche Bend Lagoon in December 1999 and in Callander's Swamp by September 1999. However, Aulacoseira numbers increased to $\sim 20 \%$ at Lake Hattah, when it was isolated and on a trend of increasing salinity in the summer of 1998/1999. Despite this, the evidence suggests that peaks (of $>20 \%$ ) of Aulacoseira granulata in sediment records from Murray River floodplain wetlands reflect periods of river flooding and that even small frequencies may reflect Murray River connection. Further monitoring of the, Murray River, distributors and wetlands at times of flooding is required to firmly establish this link.
Although exceptions are evident, the records from these three wetlands suggest that small Fragilariaceae prevail during fresh to oligosaline, mesotrophic, lagoonal conditions. This in-lake monitoring is most instructive for the interpretation of fossil sequences from River Murray floodplain wetlands, such as Tareena Billabong (Bulpin 2000) and Lake Cullulleraine (Fluin 2002), that might otherwise rely on transfer functions based largely on samples collected from wetlands in a different environmental and chemical context.

The data strongly demonstrate the dominance of salinity over nutrients on diatom assemblages once wetland conductivities exceed $\sim 2000 \mu \mathrm{S} \mathrm{cm}^{-1}$. Conductivity emerged as the strongest parameter in ordination outputs from both Callander's Swamp and Psyche Bend Lagoon, despite both wetlands recording elevated $\mathrm{TN}$ and $\mathrm{TP}$ concentrations throughout much of the survey period. At Callander's Swamp, nutrients, dissolved oxygen and temperature were influential until conductivities reached $\sim 1400 \mu \mathrm{S} \mathrm{cm}^{-1}$ then brackish water tolerant taxa such as Tryblionella hungarica and Tryblionella levidensis predominated. Also, despite TN values in excess of $6 \mathrm{mg} \mathrm{L}^{-1}$ and TP values in excess of $0.8 \mathrm{mg} \mathrm{L}^{-1}$, diatom assemblages at Lake Hattah shifted to essentially brackish water taxa such as Tryblionella apiculata and Tryblionella calida once conductivity values exceeded 1,400 $\mu \mathrm{S} \mathrm{cm} \mathrm{cm}^{-1}$. In several instances, Cyclotella meneghiniana, one of the few eutraphentic taxa to tolerate 


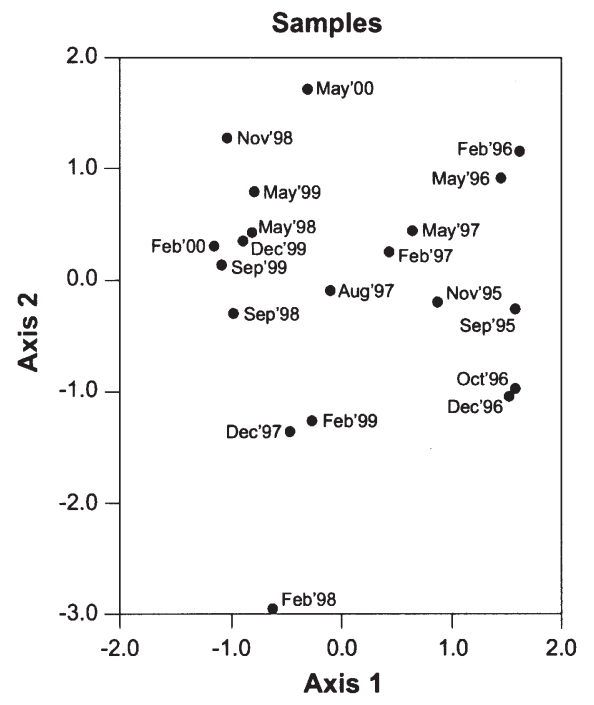

PSYCHE BEND LAGOON
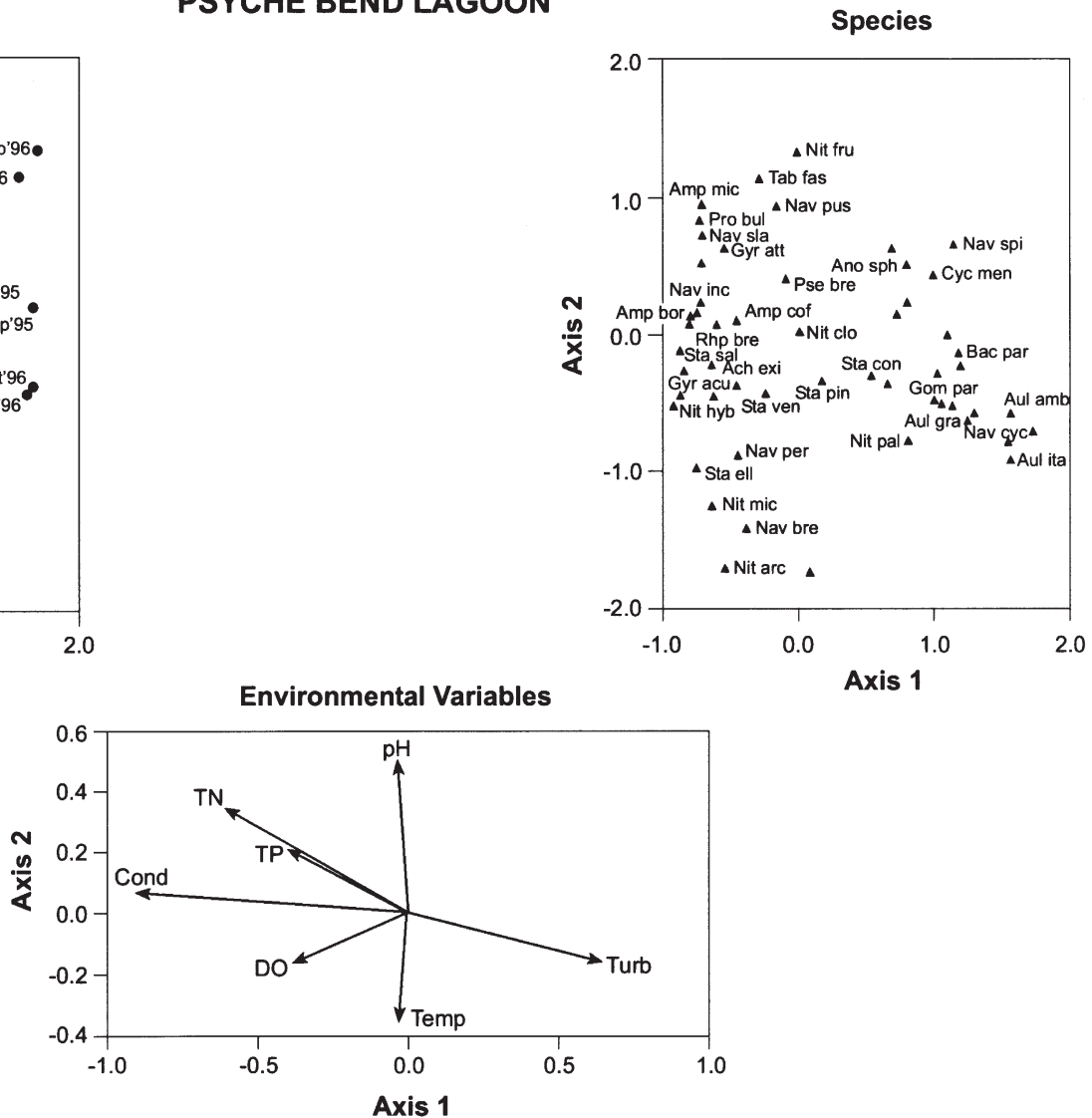

Fig. 7. Constrained ordination of diatom assemblages and physico-chemical data from Psyche Bend Lagoon (Sep. 1995 to Dec. 1999). Ach exi $=$ Achanthes exigua $;$ Amp bor $=$ Amphora coffeaeformis var. borealis; Amp cof $=$ Amphora coffeaeformis var. coffeaeformis $;$ Amp mic = Amphora micrometra $;$ Ano sph = Anomoeoneis sphaerophora $;$ Aul amb = Aulacoseira ambigua $;$ Aul gra $=$ Aulaceseira granulata $; \mathrm{Aul}$ ita $=$ Aulacoseira italica $; \mathrm{Bac}$ par $=$ Bacillaria paradoxa $;$ Cyc men =Cyclotella meneghiniana $;$ Gom par $=$ Gomphonema parvulum; Gyr att = Gyrosigma attenuatum; Nav bre = Navicula bremensis; Nav pus = Navicella pusilla $;$ Nav cyc $=$ Navicula cryptocephala $;$ Nav inc $=$ Navicula incertata $;$ Nit per $=$ Nitzschia perminuta $;$ Nav sla = Navicula salinicola $;$ Nav spi $=$ Navicula spicula $;$ Nit arc = Nitzschia archibaldii $;$ Nit clo = Nitzschia closterium; $\mathrm{Nit}$ fru $=$ Nitzschia frustulum $; \mathrm{Nit}$ hyb $=$ Nitzschia hybrida $;$ Nit mic $=$ Nitzschia microcephala $;$ Nit pal $=$ Nitzschia palea $;$ Pse bre $=$ Pseudostaurosira brevistriata $;$ Pro bul $=$ Proshkinia bulnheimii $; \mathrm{Rhp}$ bre $=$ Rhopalodia brebissonii; Sta con $=$ Staurosira construens var. construens; Sta ell = Staurosira elliptica; Sta pin $=$ Staurosirella pnnata $;$ Sta sal $=$ Staurophora salina $;$ Sta ven $=$ Staurosira construens forma venter $;$ Tab fas $=$ Tabularia fasciculata .

elevated salinities, was co-dominant when brackish and eutrophic conditions coincided.

The shifts in diatom assemblages recorded from these wetlands accord well with the documented ecological preferences (Gasse 1986; Van dam et al. 1994; Gell 1997; Sonneman et al. 2000) of the dominant taxa. Species assemblages are therefore a good predictor of the physicochemistry of a wetland at the time of sampling. Although it is not true to say, from this evidence, that a single epipelic sample taken from the littoral zone adequately characterizes the diatom flora of a wetland, it does appear sufficient to biologically interpret a wetland's general physico-chemistry. Such periphytic (non-planktonic) samples are often used as a basis for transfer functions for palaeolimnological reconstruction (Gasse et al. 1995; Gell 1997) as they contain living or recently dead cells and so are finely tuned to the chemistry of the water sample collected at the same time (Gasse et al. 1997). Ongoing monitoring can strengthen the output of statistically based reconstructions, because it may provide data on the source of the waters and thus inform critical issues of connection between the Murray River and the wetlands.

\section{Acknowledgments}

The Victorian Department of Natural Resources and Environment and the Community Implementation Groups of the 'Mallee Dryland', 'Sunraysia', 'Nyah to Border' and the 'Nangiloc-Colignan' Salinity Management Plans funded 
this research. Chris Crothers drafted Fig. 1. Chris Grivell prepared diatom samples and Amdel and the Australian Water Quality Centre undertook water chemistry analyses.

\section{References}

Battarbee, R. W. (1986). Diatom analysis. In 'Handbook of Holocene Palaeoecology and Palaeohydrology'. (Ed. B. E. Berglund.) pp. 527-70. (John Wiley: Chichester, UK.)

Bennion, H. (1994). A diatom-phosphorus transfer-function for shallow, eutrophic ponds in southeast England. Hydrobiologia 275/276, 391-410.

Bulpin, S. (2000). 'Tareena Billabong: A Window to 5000 years of Environmental Change on the Lower River Murray.' Unpublished Honours Thesis. (The University of Adelaide: Australia.)

Cumming, B. F., Wilson, S. E., Hall, R. I., and Smol, J. P. (1995). Diatoms from British Columbia (Canada) lakes and their relationship to salinity, nutrients and other limnological variables. Bibliotheca Diatomologica 31, 1-207.

Davis, M. (1987). Retrospective studies. In 'Long Term Studies in Ecology'. (Ed. G. E. Likens.) pp. 71-89. (Springer-Verlag: New York, USA.)

Dixit, S. S., Smol, J. P., Kingston, J. C., and Charles, D. F. (1992). Diatoms: powerful indicators of environmental change. Environmental Science and Technology 26, 23-33.

Fluin, J. (2002). A Diatom-based Palaeolimnological Investigation of the Lower Murray River (south-east Australia). Unpublished PhD. Thesis. (Monash University: Melbourne, Australia.)

Fourtanier, E., and Kociolek, P. (1999). Catalogue of the diatom genera. Diatom Research 14, 1-190.

Fritz, S. C., Juggins, S, and Battarbee, R. W. (1993). Diatom assemblages and ionic characterization of lakes of the northern Great Plains, N. A.: a tool for reconstructing past salinity and climate fluctuations. Canadian Journal of Fisheries and Aquatic Sciences 50, 1844-56.

Gasse, F. (1986). East African diatoms. Taxonomy and ecological distribution. Bibliotheca Diatomologica 2, 1-201.

Gasse, F., Juggins, S., and Ben Khelifa, L. (1995). Diatom-based transfer functions for inferring hydrochemical characteristics of African palaeolakes. Palaeogeography, Palaeoclimatology, Palaeoecology 117, 31-54.

Gasse, F., Barker, P., Gell, P. A., Fritz, S., and Chalié, F. (1997). Diatominferred salinity in palaeolakes: an indirect tracer of climate change. Quaternary Science Reviews 16, 547-63.

Gell, P. A. (1997). The development of a diatom data base for inferring lake salinity: towards a quantitative approach for reconstructing past climates. Australian Journal of Botany 45, 389-423.

Grimm, E. C. (1992). 'TILIA Version 1.12.' (Illinois State Museum: Springfield, USA.)

Hill, M. O. (1973). Diversity and evenness: a unifying notation and its consequences. Ecology 54, 427-32.

Hotzel, G., and Croome, R. (1996). Population dynamics of Aulacoseira granulata (HER) Simonsen (Bacillariophyceae, Centrales), the dominant alga in the Murray River, Australia. Archiv fur Hydrobiologie 136, 191-215.

Krammer, K., and Lange-Bertalot, H. (1986). 'Susswasserflora von Mitteleuropa. Bacillariophyceae, Teil i: Naviculaceae.' (Gustav Fischer Verlag: Stuttgart, Germany.)

Krammer, K., and Lange-Bertalot, H. (1988). 'Susswasserflora von Mitteleuropa. Bacillariophyceae Teil ii: Bacillariaceae, Epithemiaceae, Surirellaceae.' (Gustav Fischer Verlag: Stuttgart, Germany.)
Krammer, K., and Lange-Bertalot, H. (1991a). 'Susswasserflora von Mitteleuropa. Bacillariophyceae Teil iii: Centrales, Fragilariaceae, Eunotiaceae.' (Gustav Fischer Verlag: Stuttgart, Germany.)

Krammer, K., and Lange-Bertalot, H. (1991b). 'Susswasserflora von Mitteleuropa. Bacillariophyceae Teil iv: Achnanthaceae.' (Gustav Fischer Verlag: Stuttgart, Germany.)

Macumber, P. G. (1991). 'Interaction Between Ground Water and Surface Systems in Northern Victoria.' (Department of Conservation and Environment: Melbourne, Australia.)

Reid, M. A., Tibby, J., Penny, D., and Gell, P. (1995). The use of diatoms to assess past and present water quality. Australian Journal of Ecology 20, 57-64.

Round F. E., Crawford, R. M., and Mann, D. G. (1990). 'The Diatoms: Biology and Morphology of the Genera.' (Cambridge University Press: Cambridge, UK.)

Sluiter, I. R. K. (1996a). 'Mallee Dryland SMP Mandatory Environmental Monitoring Report.' Ogyris Ecological Research Report No. 96/07. (Ogyris Ecological Research Pty Ltd, Australia.)

Sluiter, I. R. K. (1996b). 'Nangiloc-Colignan SMP Mandatory Environmental Monitoring Report.' Ogyris Ecological Research Report No. 96/08. (Ogyris Ecological Research Pty Ltd, Australia.)

Sluiter, I. R. K. (1996c). 'Nyah to the Border SMP Mandatory Environmental Monitoring Report.' Ogyris Ecological Research Report No. 96/09. (Ogyris Ecological Research Pty Ltd, Australia.)

Sluiter, I. R. K. (1996d). 'Sunraysia SMP Mandatory Environmental Monitoring Report.' Ogyris Ecological Research Report No. 96/10. (Ogyris Ecological Research Pty Ltd, Australia.)

Sonneman, J., Sincock, A., Fluin, J., Reid, M., Newall, P., Tibby, J., and Gell, P. (2000). 'An Illustrated Guide to Common Stream Diatom Species from Temperate Australia.' Cooperative Research Centre for Freshwater Ecology Identification Guide No. 33. (Cooperative Research Centre for Freshwater Ecology: Thurgoona, Australia.)

Stephenson, A. E. (1986). Lake Bungunnia - a Plio-Pleistocene megalake in southern Australia. Palaeogeography, Palaeoclimatology, Palaeoecology 57, 137-56.

ter Braak, C. J. F. (1988). 'CANOCO - a FORTRAN Program for Canonical Community Ordination by [Partial] [Detrended] [Canonical] Correspondence Analysis, Principal Components Analysis and Redundancy Analysis (Version 2.1).' Technical report LWA-88-02. (Agricultural Mathematics Group: Wageningen, The Netherlands.)

ter Braak, C. J. F. (1990). 'Update Notes: CANOCO Version 3.10.' (Agricultural Mathematics Group: Waginingen, The Netherlands.)

Thoms, M. C., Ogden, R. W., and Reid, M. A. (1999) Establishing the condition of lowland floodplain rivers: a palaeo-ecological approach. Freshwater Biology 41, 407-23.

Van Dam, H., Mertens, A., and Sinkeldam, J. (1994). A coded checklist and ecological indicator values of freshwater diatoms from the Netherlands. Netherlands Journal of Aquatic Ecology 28, 117-33.

Walker, K., and Thoms, M. C. (1993). Environmental effects of flow regulation on the Lower River Murray, Australia. Regulated Rivers: Research and Management 8, 103-19.

Walker, K. F., Puckridge, J. T. and Blanch, S. J. (1997). Irrigation development on Cooper Creek, central Australia - prospects for a regulated economy in a boom-and-bust ecology. Aquatic Conservation 7, 63-73.

Manuscript submitted 19 February 2001; revised and accepted 5 March 2002 